\title{
Tomato Response to Starter Fertilizer, Polyethylene Mulch, and Level of Soil Phosphorus
}

\author{
V.P. Grubinger ${ }^{1}$, P.L. Minotti ${ }^{2}$, H.C. Wien ${ }^{3}$, and A.D. Turneti \\ Department of Fruit and Vegetable Science, Cornell University, Ithaca, NY 14853
}

Additional index words. Lycopersicon esculentum, branching, plant analysis, nutrient concentration

\begin{abstract}
Unmulched and polyethylene-mulched tomatoes (Lycopersicon esculentum Mill.) were grown with and without starter fertilizer (SF) in four field experiments. The fields varied as to residual $P$ level and the amount of $P$ incorporated before planting. No benefits from SF were obtained on a soil with high residual $P$ that was moderately fertilized with $P$ before transplanting or on a soil with low residual $P$ that was heavily fertilized with $P$. A positive effect from SF was observed only when residual $P$ was low and no $P$ was broadcast, and this was true in mulched and umnulched plots. No significant SF by mulch interaction was obtained in these experiments even though mulching consistently increased shoot $P$ concentrations and fruit yield. The mulch was beneficial even under conditions where unmulched tomato leaves contained $0.4 \%$ P 3 weeks after transplanting, indicating that factors in addition to improved $P$ nutrition are also involved in the mulch effect.
\end{abstract}

Commercial growers routinely use soluble SF when setting transplants of tomatoes and other vegetables. This practice is based on early research that firmly established the benefits of SF under the conditions of the experiments. For example, Arnold (1953) demonstrated large responses by a tomato crop to SF that was high in $\mathrm{P}$ on a low-P soil. This response, however, was proportionately reduced as the $\mathrm{P}$ level of the soil increased until no response was obtained at the highest soil P level. Jones and Warren (1954) similarly showed that use of a SF high in P markedly increased tomato yields and early P uptake on a soil testing low in P. In contrast to Arnold, however, they noted that the positive effect, although somewhat reduced, was not lost even when the low-P soil was heavily fertilized with $\mathrm{P}\left(147 \mathrm{~kg} \cdot \mathrm{ha}^{-1}\right)$. Jones and Warren stressed that early P uptake was more important for increasing yields than total $\mathrm{P}$ uptake because those of their fertilizer treatments that only increased late P uptake had little effect on yield.

Since the effect of polyethylene mulch in increasing the early $\mathrm{P}$ uptake of tomatoes is now well established (Wien and Minotti, 1987; 1988a 1988b), we hypothesized that the mulch might overide any beneficial effects of SF, particularly when there is a history of substantial P fertilization, which is typical for most vegetable operations. Therefore, the objective of the field experiments reported herein was to compare the response of tomatoes to SF in mulched and unmulched situations on sites that varied in residual $\mathrm{P}$ and the amount of $\mathrm{P}$ incorporated before planting. Additionally, we hoped to gain insight as to how important improved early P nutrition might be in the beneficial mulch effects previously observed by us and others.

\section{Materials and Methods}

Four field experiments were conducted from 1985 to 1987 at the Homer C. Thompson Vegetable Research Farm in Freeville, New York, on a Howard gravelly loam soil (loamy-skeletal, mixed

Received for publication 13 Jan. 1992. Accepted for publication 12 Sept. 1992. Cornell Univ. Dept. of Fruit and Vegetable Science paper no. 22. The cost of publishing this paper was defrayed in part by the payment of page charges. Under postal regulations, this paper therefore must be hereby marked advertisement solely to indicate this fact.

${ }^{1}$ Former Graduate Assistant. Current address: Univ. of Vermont Extension Service, Box 2430, Brattleboro, VT 05301.

${ }^{2}$ Associate Professor.

Professor.

${ }^{4}$ Graduate Assistant. mesic Glossoboric Hapludalf). The experimental plots in 1985 were located on a site with a history of vegetable production and previous fertilization and tested high with respect to $\mathrm{P}$ and $\mathrm{K}$, whereas the 1986 and 1987 plots were located on a site previously in a meadow that had not received fertilizer for several years and tested low in $\mathrm{P}$ and $\mathrm{K}$ (Table 1). The experiments used arandomized complete-block design with four replications. Analysis of variance was performed on the data using SAS version 5.0.

Seedlings ('Castle King' in 1985, 'Pik-Red' in 1986 and 1987) were raised in Todd planter trays (Sun City, Fla.) of $80 \mathrm{ml}$ individual cell volume that contained peat-vermiculite artificial soil mix. After 4 to 5 weeks in the polyethylene covered greenhouse, they were transplanted to the field. Single-row plots were spaced $183 \mathrm{~cm}$ apart with an in-row plant spacing of $61 \mathrm{~cm}$. Water or the designated starter solution was applied at $500 \mathrm{ml}$ to each plant shortly after transplanting. In all cases, the starter solutions were applied to provide $0.6 \mathrm{~g}$ of soluble P per plant, which amounts to $9.6 \mathrm{~kg} \mathrm{P} / \mathrm{ha}$ at the plant population used.

In 1985, the effect of three SF regimes (water, 15-7-14 and 1015-0) was compared in bare ground and clear polyethylenemulched plots. The analysis of starter refers to percentage of N, P, and $\mathrm{K}$ by weight, respectively. Thus, although the amount of $\mathrm{P}$ applied in this manner remained constant, as indicated above, the amount of $\mathrm{N}$ and $\mathrm{K}$ was variable across SF treatments. For the 1985 experiment, fertilizer was broadcast before plowing and harrowing (Table 1). Nitrogen was disked in before laying of the mulch and transplanting.

In 1986, mulching with black polyethylene without SF was compared to three bare-ground starter treatments (water, 20-9-17 and 10-15-0) on the low-P site to which no preplant $\mathrm{P}$ was added.

In 1987, two experiments were conducted on adjacent plots at the low-P site. One experiment received a preplant broadcast application of $147 \mathrm{~kg} \cdot h \mathrm{~h}^{-1} \mathrm{P}$ as single superphosphate, while the otherwise identical experiment received no preplant $\mathrm{P}$ application (Table 1). Both experiments compared the effects of SF (water vs. 10-15-0) under three mulch regimes (bare ground, clear, and black polyethylene). In 1986-87, the fertilizer was incorporated just before laying of the mulches (Table 1). In all years the mulches were $0.03 \mathrm{~mm}$ thick and $122 \mathrm{~mm}$ wide. Soils were well charged with moisture when the mulches were laid.

First fruit harvests typically came $\approx 75$ days after field setting,

Abbreviations: DAT, days after transplanting; SF, starter fertilizer. 
Table 1. Soil test' values for and fertilization of the four experiments.

\begin{tabular}{lccccccccc}
\hline \hline & \multicolumn{3}{c}{ Soil test values $\left(\mathrm{mg} \cdot \mathrm{kg}^{-1}\right)$} & & & \multicolumn{3}{c}{ Fertilization $\left(\mathrm{kg} \cdot \mathrm{ha}^{-1}\right)$} \\
\cline { 2 - 4 } \cline { 8 - 10 } Year & $\mathrm{P}$ & $\mathrm{K}$ & $\mathrm{Mg}$ & $\mathrm{Ca}$ & $\mathrm{pH}$ & $\mathrm{N}$ & $\mathrm{P}$ & $\mathrm{K}$ \\
\hline 1985 & 14 & 112 & 143 & 1485 & 6.7 & 84 & 45 & 85 \\
1986 & 3 & 25 & 386 & 1627 & 6.9 & 112 & 0 & 187 \\
1987 & 2 & 23 & 367 & 1462 & 6.9 & & 112 & 0 & 187 \\
1987 & 2 & 28 & 314 & 1235 & 6.9 & & 112 & 147 & 187
\end{tabular}

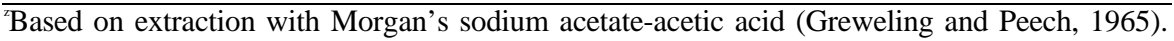

Table 2. The effect of SF and polyethylene mulches on the yield and leaf macronutrient concentration of 'Castle King' tomato leaves 24 DAT on a high P site with a history of P fertilization, 1985 (no significant starter $\mathbf{x}$ mulch interaction).

\begin{tabular}{|c|c|c|c|c|c|c|c|}
\hline \multirow[b]{2}{*}{ Variable } & \multicolumn{3}{|c|}{ Concn in leaves $(\%)$} & \multirow[t]{2}{*}{, } & \multicolumn{3}{|c|}{ Marketable yield $\left(\mathrm{t} \cdot \mathrm{ha}^{-1}\right)$} \\
\hline & Total $N$ & $\mathrm{P}$ & $\mathrm{K}$ & & Early & Mid-season & Total \\
\hline & & & Starter & & & & \\
\hline \multicolumn{8}{|l|}{$(\mathrm{N}-\mathrm{P}-\mathrm{K})$} \\
\hline $0-0-0$ & 3.10 & 0.28 & 2.14 & & 5.5 & 10.1 & 53.8 \\
\hline $15-7-14$ & 3.15 & 0.29 & 2.27 & & 6.4 & 11.7 & 61.4 \\
\hline $10-15-0$ & 3.20 & 0.29 & 1.92 & & 4.9 & 10.4 & 55.8 \\
\hline $\begin{array}{l}\text { Significance } \\
\text { LSD }(0.05)\end{array}$ & NS & NS & $\begin{array}{l}* \\
0.27 \\
\text { Mulch }\end{array}$ & $t:$ & NS & NS & NS \\
\hline Unmulched & 3.19 & 0.23 & 2.14 & & 4.5 & 9.4 & 54.6 \\
\hline Clear & 3.06 & 0.34 & 2.08 & & 6.6 & 12.1 & 59.4 \\
\hline Significance & $*$ & $* * *$ & NS & & $* *$ & $* *$ & NS \\
\hline
\end{tabular}

Early, to 20 Aug.; mid-season, to 30 Aug., and includes early yield.

Ns, $, *,+, *+*$ Nonsignificant or significant at $P=0.05,0.01$, or 0.001 , respectively.

Table 3. The effect of SF and black polyethylene mulch on leaf tissue concentrations of major nutrient? and yield of 'Pik-Red' tomato grown on a low-P soil in 1986.

\begin{tabular}{|c|c|c|c|c|c|c|c|}
\hline \multirow[b]{2}{*}{ Variable } & \multicolumn{4}{|c|}{ Concn in leaves (\%) } & \multicolumn{3}{|c|}{ Marketable yield $\left(\mathrm{t} \cdot \mathrm{ha}^{-1}\right)^{y}$} \\
\hline & Total N & $\mathrm{NO}_{3}-\mathrm{N}$ & $\mathbf{P}$ & $\mathrm{K}$ & Early & Main-season & Total $^{x}$ \\
\hline \multicolumn{8}{|l|}{$\overline{(\mathrm{N}-\mathrm{P}-\mathrm{K})}$} \\
\hline $0-0-0$ & 3.42 & 0.14 & 0.15 & 2.44 & 17.0 & 36.1 & 71.4 \\
\hline $20-9-17$ & 3.12 & 0.15 & 0.14 & 2.54 & 20.3 & 54.7 & 76.7 \\
\hline $10-15-0$ & 3.25 & 0.14 & 0.16 & 2.57 & 25.5 & 56.8 & 81.6 \\
\hline \multicolumn{8}{|l|}{ Black poly- } \\
\hline ethylene & 3.67 & 0.21 & 0.21 & 2.89 & 19.2 & 52.4 & 87.4 \\
\hline Significance & NS & * & $* * *$ & * & NS & $* *$ & NS \\
\hline $\mathrm{LSD}_{0.05}$ & 0.50 & 0.04 & 0.02 & 0.29 & 10.6 & 11.5 & 23.4 \\
\hline
\end{tabular}

From samples taken 21 DAT.

'Early, to 19 Aug.; main-season, to 3 Sept., and includes early marketable.

Includes green fruit at final harvest.

which was done in late May or early June, and continued until midSeptember. Samples for nutrient analysis were taken about the time of flowering and consisted of petioles and leaflets of the fifth or sixth leaf down from the top of the plant. Samples from six plants per experimental unit were pooled, dried in an oven at $70 \mathrm{C}$, and ground through a sieve with $0.64 \mathrm{~mm}$ openings. Subsamples were analyzed for $\mathrm{N}$ and other nutrients using a micro-Kjeldahl method and a method for inductively coupled plasma-atomic emission spectroscopy (ICP), which are standard procedures for the plant analytical laboratory of the Dept. of Fruit and Vegetable Science.

For the $\mathrm{N}$ analysis, $100 \mathrm{mg}$ of ground sample was digested with $3.0 \mathrm{ml}$ of concentrated sulfuric acid and $1.0 \mathrm{ml}$ of $30 \%$ hydrogen peroxide at $300 \mathrm{C}$ for $3 \mathrm{~h}$. After the sample had cooled, $1.0 \mathrm{ml}$ of hydrogen peroxide was added, and the sample was reheated for a minimum of $2 \mathrm{~h}$. After it cooled, the sample was diluted to $50 \mathrm{ml}$ with distilled water. Then $0.15 \mathrm{ml}$ of the diluted sample was added to $2.0 \mathrm{ml}$ of a solution of $8.5 \%$ sodium salicylate and $0.03 \%$ nitroferricyanide. Color development was initiated by adding 2.0 $\mathrm{ml}$ of a solution containing $1.5 \mathrm{~g}$ sodium dichloroisocyanurate/liter and $48 \mathrm{~g}$ sodium hydroxide/liter. Color was allowed to develop for $1 \mathrm{~h}$. The solution was further diluted with $20 \mathrm{ml}$ of distilled water, mixed thoroughly, and read at $660 \mathrm{~nm}$ using a $10 \mathrm{~mm}$ flow through cell.

For the ICP analysis, 200 to $400 \mathrm{mg}$ of sample was weighed into a quartz test tube and dry ashed for $6 \mathrm{~h}$ at $450 \mathrm{C}$ in a muffle furnace. The ashed sample was cooled, and $0.25 \mathrm{ml}$ of $30 \%$ hydrogen peroxide was added. The sample then was re-ashed at $450 \mathrm{C}$ for an additional $2 \mathrm{~h}$. Then, $0.5 \mathrm{ml}$ of $37 \%$ hydrochloric acid was added 
Table 4. The effect of SF and polyethylene mulches on the branching of 'Pik-Red' tomato on a low $\mathrm{P}$ site receiving no broadcast $\mathrm{P}$ fertilizer in 1987.

\begin{tabular}{|c|c|c|}
\hline \multirow[b]{3}{*}{ Mulch } & \multicolumn{2}{|c|}{ Branch count per plant ${ }^{2}$} \\
\hline & \multicolumn{2}{|c|}{$\mathrm{SF}(\mathrm{N}-\mathrm{P}-\mathrm{K})$} \\
\hline & $(0-0-0)$ & $(10-15-0)$ \\
\hline None & 4.0 & 7.8 \\
\hline Black & 5.3 & 7.9 \\
\hline Clear & 7.4 & 8.4 \\
\hline Significance & $* * *$ & NS \\
\hline Starter $\times$ mulch interaction & & \\
\hline
\end{tabular}

Main stem branches $>5 \mathrm{~cm}, 29$ DAT.

Ns, $* * * *$ Nonsigniflcant or significant at $P=0.5$ or 0.001 , respectively.

to dissolve the ash. After $1 \mathrm{~h}$, a diluent of $9.5 \mathrm{ml}$ of distilled water containing $4.0 \mu \mathrm{g}$ of yttrium, au internal standard, was added with sufficient force to mix the sample, which then was run on the ICP. Nitrate-N was determined electrochemically as in Minotti et al. (1989).

\section{Results}

1985 experiment. Although we had expected to see a yield response to SF in the bare-ground plots but not in the mulch plots, this was not the case. The inclusion of SF did not affect yields or $\mathrm{P}$ concentrations in either the mulched or the bare-ground plots, and there was no significant mulch $\mathrm{x}$ SF interaction for yield or for tissue concentrations of $\mathrm{N}, \mathrm{P}$, or $\mathrm{K}$ (Table 2). The 15-7-14 starter increased tissue concentration of $\mathrm{K}$ as compared to the 10-15-0, but neither differed significantly in this respect from the water control. The former, of course, contained $\mathrm{K}$ and also had $>50 \%$ of its $\mathrm{N}$ in the nitrate form, whereas the latter contained no $\mathrm{K}$ and all of its $\mathrm{N}$ was in the ammonium form, which might have competed with $\mathrm{K}$ for uptake before extensive nitrification occurred. As previously reported (Wienand Minotti, 1987; 1988a, 1988b), clear polyethylene mulch increased the $\mathrm{P}$ concentration of shoots sampled $\approx 3$ weeks after transplanting and increased early marketable fruit yields.

1986 preliminary experiment. The primary purpose of this experiment was to see if a low-P site would produce a response to $\mathrm{SF}$ similar to polyethylene mulch, rather than to test for a SF $\times$ mulch interaction. In contrast to 1985 , the SF did produce a positive response on this low-P site. Early symptoms of $\mathrm{P}$ deficiency were eliminated, early growth was accelerated (quantitative data not taken), and the main season yields (though not early or total yields) of marketable fruit were increased (Table 3). The SF did not affect leaf concentrations of $\mathrm{N}, \mathrm{P}$, or $\mathrm{K} 3$ weeks after transplanting, but early plant uptake would be expected to increase, since uptake is the product of growth $\mathrm{x}$ concentration. Black polyethylene mulch also accelerated early growth and eliminated $\mathrm{P}$ deficiency symptoms (quantitative data not taken) and increased marketable yields similarly to SF (Table 3). The mulch also increased leaf concentrations of $\mathrm{NO}_{3}-\mathrm{N}, \mathrm{P}$, and $\mathrm{K}$ (Table 3). Leaf $\mathrm{P}$ concentrations in bare-ground plots on this low $\mathrm{P}$ site were $<0.2 \%$.

1987 experiment (no $P$ broadcast). Because of the responsiveness of the 1986 site to SF, we decided to use this site for more extensive. experimentation comparing SF effects under both mulched and unmulched conditions as in 1985. Since we obtained no differences between a complete SF and 10-15-0 with respect to early growth and fruit yield, only the $10-15-0$ was used in the 1987 experiments.

SF increased the number of main stem branches that were longer than $5 \mathrm{~cm}$ by 29 days after transplanting (DAT) inunmulched plots, while clear polyethylene increased the average branch count in plots without SF (Table 4). There was a significant starter $x$ mulch interaction for branch count such that SF only increased branching in bare ground or black polyethylene plots, while clear polyethylene only increased branching in the plots without SF.

$\mathrm{SF}$ increased leaf concentrations of $\mathrm{N}, \mathrm{NO}_{3}-\mathrm{N}$, and $\mathrm{P}$ and also increased total fruit yields (Table 5). The mulches increased the $\mathrm{P}$ and $\mathrm{K}$ concentration of leaves and increased early and total yields. However, there was no SF $\times$ mulch interaction for either leaf nutrient concentration or yield indicating that on this low-P site the SF was still beneficial, even when the tomatoes were simultaneously benefiting from the mulches in terms of $\mathrm{P}$ uptake.

1987 experiment (147 $\mathrm{kg} \cdot \mathrm{ha} \mathrm{a}^{-1} \mathrm{P}$ broadcast). This experiment was identical in all respects to the 1987 experiment above except that it was executed on an adjacent block to which $\mathrm{P}$ had been incorporated before the mulch was laid and the transplants were set. Under this condition, the tomatoes had produced seven to nine branches by 29 DAT, and there was no significant effect of either SF or mulching on branch number (data not shown). This branch count is similar to that observed for plants given SF or for clear

Table 5. The effect of SF and polyethylene mulches on the yield and leaf macronutrient concentration of 'Pik-Red' tomato 21 DAT on a low-P site receiving no broadcast P fertilizer in 1987 (no significant starter $\times$ mulch interaction).

\begin{tabular}{|c|c|c|c|c|c|c|}
\hline \multirow[b]{2}{*}{ Variable } & \multicolumn{4}{|c|}{ Concn in leaves (\%) } & \multicolumn{2}{|c|}{ Yield $\left(\mathrm{t} \cdot \mathrm{ha}^{-1}\right)$} \\
\hline & Total N & $\mathrm{NO}_{3}-\mathrm{N}$ & $\mathrm{P}$ & $\mathrm{K}$ & Early $^{z}$ & Total \\
\hline \multicolumn{7}{|c|}{ Starter } \\
\hline \multicolumn{7}{|l|}{$(\mathrm{N}-\mathrm{P}-\mathrm{K})$} \\
\hline $0-0-0$ & 3.37 & 0.21 & 0.17 & 2.18 & 13.2 & 57.3 \\
\hline $10-15-0$ & 3.71 & 0.29 & 0.23 & 2.26 & 14.5 & 68.4 \\
\hline Significance & $* *$ & $* *$ & $* *$ & NS & NS & $* *$ \\
\hline \multicolumn{7}{|c|}{ Polyethylene mulch } \\
\hline Unmulched & 3.38 & 0.28 & 0.16 & 1.88 & 11.1 & 44.9 \\
\hline Black & 3.68 & 0.26 & 0.22 & 2.51 & 14.8 & 69.5 \\
\hline Clear & 3.57 & 0.23 & 0.22 & 2.26 & 15.7 & 74.2 \\
\hline Significance & NS & NS & $* *$ & $* * *$ & $* *$ & $* * *$ \\
\hline LSD (0.05) & 0.28 & 0.07 & 0.04 & 0.29 & 2.8 & 8.0 \\
\hline
\end{tabular}


Table 6. The effect of SF and polyethylene mulches on the yield and leaf macronutrient concentration of 'Pik-Red tomato 21 DAT on a low-P site broadcast fertilized with 147 $\mathrm{kg} \cdot \mathrm{ha}^{-1} \mathrm{P}$ in 1987 (no significant starter $\times$ mulch interaction).

\begin{tabular}{|c|c|c|c|c|c|c|}
\hline \multirow[b]{2}{*}{ Variable } & \multicolumn{4}{|c|}{ Concn in leaves $(\%)$} & \multicolumn{2}{|c|}{ Yield $\left(\mathrm{t} \cdot \mathrm{ha}^{-1}\right)$} \\
\hline & Total N & $\mathrm{NO}_{3}-\mathrm{N}$ & $\mathbf{P}$ & $\mathrm{K}$ & Early $^{z}$ & Total \\
\hline \multicolumn{7}{|c|}{ Starter } \\
\hline \multicolumn{7}{|l|}{$(\mathrm{N}-\mathrm{P}-\mathrm{K})$} \\
\hline $0-0-0$ & 3.66 & 0.39 & 0.40 & 2.22 & 13.1 & 92.2 \\
\hline $10-15-0$ & 3.69 & 0.34 & 0.46 & 1.95 & 12.6 & 93.9 \\
\hline Significance & NS & NS & NS & $*$ & NS & NS \\
\hline \multicolumn{7}{|c|}{ Polyethylene mulch } \\
\hline Unmulched & 3.71 & 0.43 & 0.41 & 1.93 & 9.2 & 86.3 \\
\hline Black & 3.74 & 0.41 & 0.50 & 2.34 & 14.1 & 98.4 \\
\hline Clear & 3.58 & 0.27 & 0.39 & 1.97 & 15.2 & 94.4 \\
\hline Significance & NS & $*$ & $* *$ & $* *$ & $* *$ & NS \\
\hline LSD (0.05) & 0.31 & 0.12 & 0.07 & 0.26 & 3.3 & 13.9 \\
\hline
\end{tabular}

mulched plants that received no preplant $\mathrm{P}$ grown on the adjacent low-P site.

The SF caused no change in the tissue concentrations of $\mathrm{N}$ and $\mathrm{P}$ but slightly decreased $\mathrm{K}$ concentrations (Table 6 ). Tissue $\mathrm{P}$ was generally twice as high $(\approx 0.4 \%)$ as in the adjacent site (Table 5 vs. Table 6). Black, but not clear mulch, also increased leaf $\mathrm{P}$ and $\mathrm{K}$ concentrations. Although fruit yields were not affected by SF in this experiment, early yield was increased an average of $59 \%$ by the polyethylene mulches. There was no significant SF x mulch interaction for either fruit yield or leaf nutrient concentration in this experiment.

\section{Discussion}

Effect of starter fertilizers. Because we had observed that polyethylene mulching consistently increased the early growth and $\mathrm{P}$ concentrations of tomatoes transplanted to the field, we hypothesized that the use of SF might be superfluous when such mulches are used under conditions of relatively high soil fertility. Considering the four experiments reported here, the only positive effect we observed from SF occurred when soil residual $\mathrm{P}$ was low and no $\mathrm{P}$ fertilizer other than the starter was applied (Tables 3 and 5). Under this low-P condition, the mulch did not overide the benefit of SF even though it did increase tissue $\mathrm{P}$, early growth, and fruit yield (Table 5).

No yield benefits from SF were observed on the soil with substantial residual $\mathrm{P}$ (Table 2 ) or on the soil with low residual $\mathrm{P}$ receiving a heavy application of $\mathrm{P}$ before transplanting (Table 6); this was true whether or not the plots were mulched. Thus, we did not obtain the mulch $\times$ SF interaction (i.e., a positive effective of SF in unmulched plots but not in mulched plots) that we expected.

These results, as far as the bare-ground treatments are concerned, agree with those of Arnold (1953), who found that tomato yield responses to a 10-23-14 starter proportionately decreased with increasing soil $\mathrm{P}$ fertility until no response was obtained at the highest residual P level used. Jones and Warren (1954) similarly observed marked positive responses from a 6-25-14 starter as compared to a 6-0-14 at low soil P levels, but in contrast to our results and those of Arnold, the positive effect was not lost, even when soils were supplemented with $147 \mathrm{~kg} \cdot \mathrm{ha}^{-1}$ of P. Neither of these investigators worked with mulch, however.

Soil test $\mathrm{P}$ values (Morgan's extracting solution) for the low-P sites used in the present experiments were 2 to $3 \mathrm{mg} \cdot \mathrm{kg}^{-1}$ of $\mathrm{P}$, which is considered low according to Cornell calibration standards. Thus, substantial $\mathrm{P}$ would have been recommended on such a site. Soil $\mathrm{P}$ values for 327 commercial vegetable soil samples sent to the Cornell Nutrient Analysis Lab in Spring 1990 averaged $56 \mathrm{mg} \cdot \mathrm{kg}^{-1}$ (Minotti, unpublished), which is about three times the residual $\mathrm{P}$ in the 1985 experiment (Table 1) where no response to SF was obtained with a moderate rate of $\mathrm{P}$ fertilization. Only $12 \%$ of the samples submitted tested $3 \mathrm{mg} \cdot \mathrm{kg}^{-1} \mathrm{P}$ or less. Moreover, most tomato transplants are grown in artificial media and fertilized with soluble fertilizer within a few days of transplanting to the field. It, therefore, appears that use of SF as standard operating procedure for setting tomato transplants would not be cost effective in the majority of situations, at least under New York conditions.

Role of $P$ nutrition in the mulch effect. Research by others has also shown that polyethylene mulch, laid over soils well charged with moisture, can speed the development of transplanted tomatoes and increase their fruit yield (Austin, 1964; Carolus and Downs, 1958; Chipman, 1961; Rudich, 1979). In our previously reported tomato mulch experiments (Wien and Minotti, 1987; 1988a, 1988b), polyethylene mulch usually, but not always, in-

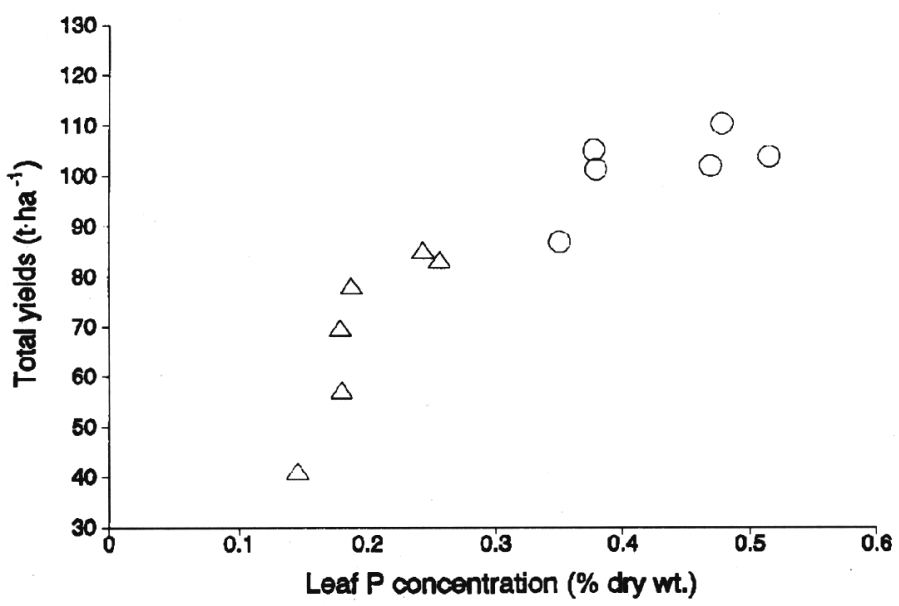

Fig. 1. The relationships between leaf $\mathrm{P}$ concentration measured 21 DAT and total yield of (Pik-Red) tomatoes grown on two sites differing in soil-applied $\mathrm{P}$ and mulched with one of three types of polyethylene in $1987(\Delta$, no $\mathrm{P} ; 1$, $147 \mathrm{~kg} \cdot \mathrm{ha}^{-1} \mathrm{P}$ ). 
creased the $\mathrm{K}$ concentration of shoots; it sometimes increased and sometimes decreased $\mathrm{N}$ and $\mathrm{NO}_{3}-\mathrm{N}$ concentrations, but it always increased $\mathrm{P}$ concentrations. For example, in five separate experiments, other than those reported here, the 1eaf $\mathrm{P}$ concentrations of unmulched tomatoes compared to mulched tomatoes 3 weeks after transplanting were 0.29 vs $0.45,0.38$ vs $0.49,0.24$ vs $0.36,0.29$ vs 0.36 , and 0.22 vs 0.34 in percentage of dry weight. These increases in $\mathrm{P}$ concentration occurred in spite of the concurrent accelerated growth that would tend to dilute nutrient concentrations. Phosphorus levels of $0.3 \%$ or lower have been cited as "low," "deficient," "critical," or "marginal" for young tomato shoots ( Jones, et al., 1991; Lingle, 1960; Piggott, 1986). For the 1987 experiments reported here, the yield response of tomatoes to practices that increased tissue $\mathrm{P}$ concentration resulted in an asymptotic relationship that reached a plateau somewhere between $0.3 \%$ and $0.4 \% \mathrm{P}$ (Fig 1).

In view of the above, we speculate that a large part of the beneficial mulch effect resides in overcoming limitations to $\mathrm{P}$

\section{Literature Cited}

Arnold, C.Y. 1953. Phosphorus requirements of transplanted tomatoes on heavy soils. Soil Sci. 76:405-419.

Austin, R.B. 1964. Plastic mulches for outdoor tomato crops and a trial of varieties. Expt. Hort. 11:17-22

Carolus, R.L. and J.D. Downes. 1958. Studies on muskmelon and tomato responses to polyethylene mulching. Michigan Agr.. Expt. Sta. Quart. Bul. 40:770-785.

Chipman, E.W. 1961. Studies of tomato response to mulching on ridged and flat rows. Can. J. Plant Sci. 41:10-15.

Clarkson, V.A. 1960. Effect of black polyethylene mulch on soil and microclimate temperature and nitrate level. Agron. J. 52:307-309.

Cooper, A.J. 1973. Root temperature and plant growth-a review. Commonwealth Bureau of Hort. and Plantation Crops. East Malling, England.

Emmert, E.M. and F.K. Ball. 1933. The effect of soil moisture on the availability of nitrate, phosphate, and potassium to the tomato plant. Soil Sci. 35:295-306.

Gosselin, H. and M.J. Trudel. 1983. Interactions between air and root temperatures on greenhouse tomatoes II. Mineral composition of plants. J. Amer. Soc. Hort. Sci. 108:905-909.

Greweling, T. and M. Peech. 1965. Chemical soil tests. Cornell Agr. Expt. Sta. Bul. 960. p12.

Jones, J.B., Jr., B. Wolf, and H.A. Mills. 1991. In: Plant Analysis Handbook-A Practical Sampling, Preparation, Analysis and Interpretation Guide p. 185-186. Micro-Macro Publ., Athens, Georgia.

Jones, L.G. and G.F. Warren. 1954. The efficiency of various methods of application of phosphorus for tomatoes. Proc. Amer. Soc. Hort. Sci. 63:309-319.

Knavel, D.E. and H.C. Mohr. 1967. Distribution of roots of four different vegetables under paper and polyethylene mulches. Proc. Amer. Soc. uptake. Phosphorus uptake is particularly sensitive to temperature and moisture (Emmett and Ball, 1933; Gosselin and Trudel, 1983; Locascio and Warren, 1960; Tindall et al., 1990; Wilcox et al., 1962), and the improved temperature under the mulch may stimulate root growth (Cooper, 1973; Knave1 and Mohr, 1967; Rudich, 1979; Wien et al., 1993). Increased root growth, increased $\mathrm{P}$ availability, and increased efficiency of uptake ( $\mathrm{P}$ absorbed per unit of root) could all be involved in the mulch-caused increase in shoot $\mathrm{P}$ concentration.

However, on the 1987 site heavily fertilized with $\mathrm{P}$, a beneficial mulch effect still occurred even though the unmulched plants contained 0.4\% P (Table 6). Likewise, Rudich (1979) reported that polyethylene mulch caused yield increases even in plots "intensively" fertilized with P. Therefore, although a case can be made for improved $\mathrm{P}$ nutrition as a contributing factor in the beneficial mulch effect, otherprocesses affected by improved moisture and temperature, reduced $\mathrm{N}$ leaching (Clarkson, 1960), and possibly elevated soil CO, levels (Grubinger, unpublished data) could all be involved.

Hort. Sci. 91:589-597.

Lingle, J.C. 1960. The effect of source of phosphorus on the growth and phosphorous uptake of tomato. seedlings. Proc. Amer. Soc. Hort. Sci. 76:495-502.

Locascio, S.J. and G.F. Warren. 1960. Interaction of soil temperature and phosphorus fertilization on growth of tomato seedlings. Proc. Amer. Soc. Hort. Sci. 75:601-610.

Minotti, P.L., T.J. Hankinson, V.P. Grubinger, and H.C. Wien. 1989. Whole leaves versus petioles for assessing the nitrogen status of tomatoes. HortScience 24:84-86.

Piggott, T.J. 1986. Plant Analysis-An Interpretation Manual, p 181. In: D.J. Reuter and J. B. Robinson (eds.). Inkata Press, Melbourne, Australia. Rudich, J. 1979. Growing of processing-tomato plants under waterdeficiency conditions: Mulching with transparent polyethylene. Scientia Hort. 10:117-125.

Tindall, J.A., H.A. Mills, and D.E. Radcliffe. 1990. The effect of root zone temperature on the nutrient uptake of tomato. J. Plant Nutr. 13:939-956.

Wien, H.C. and P.L. Minotti. 1987. Growth, yields and nutrient uptake of transplanted fresh market tomatoes as affected by plastic mulch and initial nitrogen rate. J. Amer. Soc. Hort. Sci. 112:759-763.

Wien, H.C. and P.L. Minotti. 1988a. Response of fresh market tomatoes to nitrogen fertilizer and plastic mulch in a short growing season. J. Amer. Soc. Hort. Sci. 113:61-65.

Wien, H.C. and P.L. Minotti. 1988b. Increasing yield of tomatoes with plastic mulch and apex removal. J. Amer. Soc. Hort. Sci. 113:342-347. Wien, H.C., P.L. Minotti, and V.P. Grubinger. 1993. Polyethylene mulch stimulates early root growth and nutrient uptake of transplanted tomatoes. J. Amer. Soc. Hort. Sci. 118:207-211.

Wilcox, G.E., G.C. Martin, and R. Lanston. 1962. Root zone temperature and phosphorus treatment effects on tomato seedling growth in soil and nutrient solutions. Proc. Amer. Soc. Hort. Sci. 80:522-529. 